Shisanya SO and Hendriks SL (2011). The contribution of community gardens to food security in the Maphephetheni uplands, determined by the Household Food Insecurity Access Scale. Development Southern Africa 28 (4): 509-526.

http://www.tandfonline.com/doi/abs/10.1080/0376835X.2011.605568?journalCode=cdsa20

\title{
The contribution of community gardens to food security in the Maphephetheni uplands
}

\author{
Stephen O Shisanya \& Sheryl L Hendriks ${ }^{1}$
}

Although community gardens are widely promoted, very little empirical evidence exists of their contribution to food security. This study evaluated the contribution of community gardens to alleviating food insecurity for 53 community gardeners in Maphephetheni, KwaZulu-Natal, South Africa. Using the Household Food Insecurity Access Scale, it was found that $89 \%$ of these households were anxious about food supplies, consumed insufficient food and were severely food insecure. In addition, $72 \%$ consumed poor quality food. Community gardens were unable to solve the problem of food insecurity, but their contribution to consumption cannot be entirely ignored. Improved productivity and appropriate agricultural and nutritional advice are necessary. Land availability needs to be addressed through community and other redress systems to grant communities access to less marginal and more accessible productive land close to water. Programmes to support nonfarm income are needed and could provide incentives for increased production.

Keywords: food security; community gardens; food consumption

\section{Introduction}

Household food insecurity results from an inability to meet daily food requirements and anxiety about the ability to produce and/or access food in future. Rural households in developing countries face a continual challenge in managing a complicated bundle of interrelated environmental, economic, social and health-related threats, stressors and shocks (Philip \& Rayham, 2004). Their ability to cope with these problems depends largely on their access to productive resources, livelihood incomes and accumulated assets and savings. Lowincome households may find this difficult, as they typically have low levels of resources, assets and savings and engage in a narrow range of livelihood activities (Minde et al., 2008). When crises strike, these households are forced to apply adaptive strategies that reduce food consumption and compromise the nutrition and productivity of household members, increasing deprivation.

\footnotetext{
${ }^{1}$ Respectively, Programmes and Projects Implementation Manager, The Valley Trust, Botha's Hill, KwaZuluNatal; and Associate Professor, Food Security, University of Pretoria. Corresponding author: sheryl.hendriks@up.ac.za
} 
The collective impact of the 2008 global high food price crisis and the subsequent high price volatility in commodities such as food, fuel, fodder and fertiliser has exacerbated hunger and poverty among the poor (FAO, 2008). Higher food prices affect marginalised and food insecure groups more severely than other segments of society, reducing purchasing power and negatively affecting food consumption (Quisumbing et al., 2008). This combination of increased input, energy and food prices puts extreme pressure on poor agricultural households' budgets. The 2008 food price crisis called attention to the fragile nature of food systems and the changing nature of food security for an increasing number of poor households, who are increasingly becoming net buyers of food (IFPRI, 2008).

The 2008 global food price crisis turned attention back to agriculture and prompted questions about the decades of under-investment by national government and international agencies. Agriculture plays a key role in poverty alleviation by driving economic growth and reducing poverty and hunger in developing countries (IFPRI, 2005; AU/NEPAD, 2009). Lack of economic growth leaves countries trapped in poverty, hunger and economic stagnation (IFPRI, 2005).

There is growing recognition that earlier discussions and assumptions about food security that focused on production ignored the reality that food self-sufficiency depends not just on agricultural production but also on access to food, even for farm households (AU/NEPAD, 2009). Poor agricultural productivity, low household incomes, high food prices, inappropriate land tenure systems and the HIV/AIDS pandemic combine to perpetuate food insecurity in many rural areas.

In 2000, about eight million South Africans were surviving on less than US\$1 per person per day and 18 million were living on less than US\$2 per person per day (UNDP, 2003). The number of people living below the poverty line (on incomes of less than R322 per month per adult equivalent in 2000 terms) increased over the period 1999-2002, with 'new' poor estimated at 4.5 million (Meth \& Dias, 2004). Data from the 2006 General Household Survey showed that $47.1 \%$ of the population did not have R322 (in 2000 prices) for essential food and non-food items (Armstrong et al., 2009). Meth and Dias (2004) speculated that the number of food insecure households could increase unless sustainable interventions to alleviate food insecurity were implemented.

The apartheid policies of segregation and discrimination have left a legacy of inequality and poverty among the rural communities in South Africa (Woolard, 2002). The Human Development Index for South Africa dropped from 0.73 in 1994 to 0.67 in 2003 and is currently 0.597 (UNDP, 2003, 2010). Approximately 65\% of South Africa's poor live in rural areas and most are chronically poor (Machethe, 2004). Kirsten and Moldenhauer (2006) report that low agricultural productivity in rural areas is a major cause of household food insecurity in South Africa, and the National Department of Agriculture has reported that limited agricultural production in the former homelands means that households are often not able to feed themselves (NDA, 2002).

Machethe (2004) observes that since most people in developing countries live in rural areas and are engaged, directly or indirectly, in agricultural activities, agriculture could be the most effective way to reduce rural poverty and food insecurity. Small-scale farming, coupled with the use of appropriate agricultural production technologies such as high yielding varieties, soil fertility enhancers and bio-fortification of stable crops are more efficient food producers in labour surplus economies, ensuring food insecurity in rural areas (Hazell \& Diao, 2005). 
Community gardens have been widely promoted as a food insecurity intervention (Malakoff, 1995; Marsh, 1998; FAO, 2007), although their impact and relative cost-effectiveness have not been well researched and documented (FAO, 2007; IFPRI, 2007). Community gardens are said to enhance household food security through direct access to diverse nutritious foods, increased purchasing power from savings on food bills, income from the sale of surplus produce, and provision of food stocks during seasonally lean periods (Chadha \& Olouch, 2003; Faber, 2007).

Maxwell et al. (2003) observe that food security is complex and entails a range of factors and elements that affect food supply, access, adequacy, utilisation, safety and cultural acceptability. Agricultural interventions contribute to food security in several ways, including direct supply of crops and animal based foods for consumption, creation of employment opportunities and access to other non-farm foods through farm produce incomes (Bonnard, 2001). Agricultural interventions could have a direct impact on food security by encouraging the diversification of production systems through community gardening, home gardening, intercropping and introduction of high value crops (Bonnard, 2001). However, to guide, monitor and evaluate the design and implementation of food security programmes, it is important to measure the impact of agricultural interventions on household food insecurity.

\section{Food security in South Africa}

The South African Constitution (Chapter 2 section 27.1b) asserts that every citizen has the right to access sufficient food and water, and the government should take appropriate legislative measures to realise this objective (HSRC, 2004). Yet large parts of southern Africa are chronically food insecure, meaning that millions do not have enough to eat even in a 'good' harvest year as a result of a series of entangled causes such as economic stagnation, decreased formal employment opportunities, poor agricultural policies, adverse climatic factors, environmental degradation and the devastating impact of HIV/AIDS (Oxfam, 2007).

A number of interlinking factors contribute to food insecurity, creating structural vulnerability that exposes people to high levels of risk and stress and undermines their ability to cope. The South African Integrated Food Security Strategy (NDA, 2002) listed the following as some of the causes of food insecurity in South Africa: inadequate safety nets, weak disaster management systems, weak support networks, inadequate and unstable household food production and lack of purchasing power. May (1998) reported that the major factors contributing to poverty and food insecurity in South Africa include the impact of apartheid that stripped people of their assets, especially land, distorted economic markets and social institutions that undermined the asset base of individuals, households and communities.

Despite South Africa's national self-sufficiency with regard to food production, however, widespread food insecurity exists (Charlton \& Rose, 2002; National Treasury, 2003). South Africa has no conclusive statistics on food security (Hendriks, 2005). What national statistics do exist (primarily on nutrition status and some on the prevalence of hunger) are inconsistently measured and not current. From the General Household Surveys the HSRC (2004) estimated that by 2001 more than 14 million people, or about $35 \%$ of South Africa's population, were vulnerable to food insecurity and more than one quarter of children under the age of six were stunted due to malnutrition These surveys show that between 2002 and 2006 there was a decline in the share of households facing hunger (Parliamentary Monitoring 
Group, 2008). The number of households where children went hungry at least 'sometimes', declined by almost half, to 800000 or $13 \%$ of all households by 2006 (Parliamentary Monitoring Group, 2008).

In 1994 the South African Vitamin A Consultative Group (SAVACG) conducted the first national nutrition study that looked at the anthropometric profile of pre-school children (VIC, 2001). The study reported that $24 \%$ of South African children were stunted and $9 \%$ were underweight. A second national survey conducted in 1999 showed that, on average, children's intakes of energy, calcium, iron, zinc, selenium, vitamins A, D, C and E, riboflavin and niacin were below two thirds of the Recommended Dietary Allowances (Labadarios et al., 2000). Half the children aged 12 to 108 months consumed less than half the recommended intakes for vitamin A, vitamin $\mathrm{C}$, riboflavin, niacin, vitamin $\mathrm{B} 6$, folate, calcium, iron and zinc. Iron deficiency anaemia was a common problem among children in rural communities - although anaemia can be caused by malaria and parasite infestations, but dietary iron deficiency is nevertheless a concern (Labadarios et al., 2000). The 1999 survey showed that the majority of children consumed diets low in energy, poor in protein quality and low in micronutrient density. Only one in four households appeared to be food secure (based on an absence of reported hunger).

Without knowing the extent of food security or insecurity trends over time, there is little hope that policies and programmes will address food insecurity in South Africa effectively (Carletto et al., 2001; UNDP, 2003). Specific knowledge about vulnerable groups and their economic characteristics in terms of location, demographics and extent of food insecurity is needed for accurate targeting to make household food security interventions more effective (Motloung \& Mears, 2002).

\section{Impact of community gardens on household food security}

A community garden is run by individuals who pledge support to a farm operation so that the farmland becomes either legally or through customary right of use (communal tenure), the community's farm, with the growers and consumers providing mutual support and sharing the risks and benefits of food production (AFSIC, 2007). The benefits of community gardens include:

- accessing fresh nutritious foods,

- promotion of physical fitness,

- knowledge and expertise gained in growing plants,

- development of skills such as shared decision making,

- problem solving and negotiation among gardeners, and

- a place where gardeners build a sense of community (ACFCGN, 2002).

Parry et al. (2005) also point out some intangible benefits: 
- Psychological well-being through positive aesthetic environmental changes - community gardeners gain a sense of pride and accomplishment, which in turn fosters feelings of self-worth and self-confidence.

- Growing food crops independently saves community gardeners from having to buy vegetables or fruit from commercial sources, thus saving them money and making them feel self-reliant.

- Opportunities arise for disenfranchised individuals to join community group efforts as active members and to take on leadership roles to work towards collective goals.

The Food and Agriculture Organisation of the UN (FAO, 2007) says that successful agricultural development projects promote food security, self-sufficiency and self-reliance (such as income generation from non-farm sources to purchase food), through greater community control of agriculture and food systems. Community gardens provide access to affordable, nutritious and diversified local food that can increase food intake, smooth consumption and represent savings, enabling households to purchase foods that they do not produce and other household essentials. However, production and access to this food depends on a number of entitlements for producing or acquiring food (FAO, 2007). These include access to productive natural resources: water, seeds and environmental services; diverse sources and kinds of knowledge (including traditional and indigenous knowledge, current best practices, locally relevant research and site-specific information); and access to market opportunities.

The ACFCGN (2002) reported that in East Timor women from 121 families worked in community gardens and produced mustard, tomato and eggplant that provided food for household consumption. Surplus produce was sold, increasing purchasing power and effectively addressing household food insecurity. Community gardens in Lesotho established in the 1960s improved the nutrition of beneficiaries by providing fresh vegetables to combat chronic malnutrition and diseases like pellagra and leprosy (Mashinini, 2001). In addition, the gardens promoted employment, income generation and empowerment of women and landless households. In the Gambia, income from gardens enabled women to take out loans to build new community vegetable gardens to increase their incomes and to pay for school fees and stationery for their children (UN, 2006).

Community garden participants in Senegal formed Rural Enterprise Promotion projects that also included product processing and preservation. The additional income was used to educate their children (UN, 2006). Mashinini (2001) observes that the increased involvement of community members in collective action and the ownership and management of natural resources is the best route to sustainable food security, because it enables resource pooling and sharing to promote efficiency and equity in the use of scarce resources. Community garden participants' willingness to share resources is enhanced by working together (Glover, Parry \& Shinew, 2005; Glover, Shinew \& Parry, 2005). Community gardens may in fact be more about community than they are about gardening, as they offer places where people gather, network and identify together as residents of a neighbourhood endeavouring to make a community effort and work towards a common goal (Parry et al., 2005).

Parry et al. (2005) caution, however, that the collective and collaborative nature of community gardening could also create and sustain social divisions or foster exclusion, or encourage homogeneity in members' ways of thinking. Community gardens are time 
consuming to organise and manage and their sustainability often relies on one or two individuals being able to coordinate the other members' activities (Parry et al., 2005). A lack of sustainable management due to conflicts related to age, gender, and economical and political power resulted in decreased productivity in community gardens in Lesotho (Mashinini, 2001).

Despite all the benefits reported in the available literature, very little empirical evidence of the impact of home and community gardens on food security is available. Studies have not used consistent approaches and their designs do not always evaluate food security indicators directly. The scant available international literature shows that home gardens can improve nutrition (dietary intake and anthropometric indicators), although exceptions have been reported (Berti et al., 2004). For example, Webb (2000) reviews three case studies of home gardens in southern Africa. Chiapa and King's study of urban farmers in Zimbabwe (1998 cited by Webb, 2000) found a significant correlation between urban agriculture and household nutrition. Webb's own study (1996, cited by Webb, 2000) in the Eastern Cape, South Africa, showed a tenuous link between food gardens and nutrition. Likewise, Schmidt and Vorster's investigation (1995, cited by Webb, 2000) of the benefits of home gardens in Slough, North West Province, South Africa, corroborated Webb's (1996) tenuous findings for the Eastern Cape.

Maunder and Meaker's analysis (2007) of the 1999 National Food Consumption Survey data showed that children from households that engaged in agriculture had better intakes of several nutrients, including vitamin A, folate, vitamin B6, vitamin $\mathrm{C}$, calcium and iron, than those from households that did not produce food. However, the scale of production, i.e. household, community or commercial production, was not recorded in the survey. Mjonono et al. (2009) investigated the food security 'coping strategies' ${ }^{2}$ of households belonging to a farmers' organisation and a representative sample of control households in Embo, KwaZuluNatal, South Africa. They showed that households with lower involvement in agriculture (home and community gardens) engaged in more erosive strategies (practising severe reduction in food consumption and selling off assets) than farming households engaged in regular smallholder commercial production. Mjonono et al. (2009) found that producing and selling food improved household food security. However, the evidence showed that vulnerability to consumption shocks was reduced only as per capita crop income increased, supporting Kirsten et al.'s findings (1998) that only when households earn income from agriculture does children's nutrition improve.

Hendriks and Msaki (2009) explored the impact of commercial organic production of traditional root crops in Embo, KwaZulu-Natal, South Africa on dietary diversity, energy consumption, micronutrient intakes and food expenditure patterns. Comparisons between fully certified organic producers selling to a formal supply chain, partially certified producers starting to engage in commercial production and non-members of the association showed that fully certified members enjoyed greater dietary diversity and better nutrition than nonmembers and members just starting to produce for this market. This too supports earlier evidence from rural South African studies that suggest that agricultural growth drives food

\footnotetext{
${ }^{2}$ Households facing food shortages engage in a number of fairly predictable behaviours that alter their food consumption, production or income patterns. The term 'coping strategy' is commonly used in the food security literature to mean the actions taken by households when they do not have enough food (Maxwell et al., 2003), even though engaging in such behaviour is usually indicative of not coping.
} 
consumption demand and can lead to beneficial dietary changes when production goes beyond subsistence requirements (Kirsten et al., 1998; Hendriks 2003; Kirsten et al., 2007).

\section{Measuring the impact of interventions on food security}

Food security is a broad and complex concept, determined by the interaction of multiple agro-physical, socioeconomic and biological factors (Riely et al., 1999). There is no single, direct measure of food security and its measurement focuses mainly on three interrelated dimensions, namely food supply, food access and food consumption (Riely et al., 1999). Depending on the proposed project, indicators of food security may be categorised into process indicators, describing food supply and food access, and outcome indicators, describing food consumption (Hoddinott, 1999).

There is an urgent need for relatively simple, methodically rigorous measures of food security (particularly of the access dimension) that can be used to guide, monitor and evaluate operational interventions (Swindale \& Ohri-Vichaspati, 2005). In response, the Food and Nutrition Technical Assistance (FANTA) set up a project to identify a scientifically validated, simple and user-friendly approach to measure the impacts of food security interventions (FANTA, 2005). Wolfe \& Frongillo (2001) assert that food insecurity has four components, two directly related to food quantity and quality, and two that are psychological and social: 'certainty', related to worry about food availability, and 'acceptability', related to how food is acquired (i.e. whether it is sourced through decent and dignified means). These four food insecurity components are captured in the US National Food Security Measure, which shows an example of a conceptually well-grounded measure based on experience of food insecurity and used as a precursor to the Household Food Insecurity Access Scale (HFIAS) (Coates et al., 2006).

The HFIAS is useful in baseline surveys as an early warning for assessing trends in food consumption related to food access, in measuring the impact of policies and interventions, and for innovative uses such as community self-monitoring food security projects and the right to food awareness (FANTA, 2007). The South African National Department of Agriculture, through the Food Security Directorate, used the HFIAS to evaluate food security in Sekhukhune, Limpopo, and found that $58.4 \%$ of households were severely food insecure (Faber et al., 2009).

\section{Study area}

This study was conducted in the Maphephetheni uplands, a rural area of KwaZulu-Natal, South Africa, approximately 80 kilometres west of Durban in the Valley of a Thousand Hills. The population of the Maphephetheni uplands was estimated at 16000 people, constituting 2000 homesteads and with an average of eight persons per household (Green et al., 2001). On average, each homestead at the time had four dwellings and typically housed an extended family (RAPS, 2004). In 1999, the average household income was estimated to be R348 per capita per month (Green \& Erskine, 1999), showing that households here were poor, falling just below the South African poverty line of R352 per month per adult equivalent (May, 1998). Income generating activities in the area were non-farm activities (selling snacks, food, 
cold drinks, beer, clothes and bead work, and repairing shoes) and farm activities (production and sales of peanuts, vegetables, chickens, eggs and goats) (Green et al., 2001).

\section{Methodology}

Between May and June 2006, 53 households that were active in community gardens in the Maphephetheni Uplands participated in this study. Meetings were held with each community garden group. Household representatives were asked to respond to a food security questionnaire. The researchers used a face-to-face survey technique, with pre-prepared prompts and probes to ensure adequate understanding of the questions. This kind of survey was chosen because of the low level of literacy in the area (Green et al., 2001), and to ensure adequate completion of the questionnaires.

In order to adapt the HFIAS questions, definitions and examples to the local context and ensure that questions were understood correctly, the questionnaire was reviewed using the HFIAS guidelines set out by Coates et al. (2006:18-20). Data from the Maphephetheni uplands food consumption survey (Chingondole, 2006) supplemented the data collected for this study. Descriptive statistics, Spearman's and Pearson's correlation coefficient, cross tabulations and one-way analysis of variance were used in data analysis. Only significant relationships are reported in the section below.

\section{Anxiety and uncertainty about household food supply}

Eighty-nine per cent of respondents said they had been anxious and uncertain about accessing enough food in the past 30 days (Table 1). Households had lost crops because of theft, animal damage, floods and drought. The gardens were located on agriculturally marginal land, making it difficult to grow good crops, far from their homesteads, making the crops vulnerable to theft, and unfenced, which meant that animals could get in and eat or damage the crops.

Table 1: Households' anxiety and uncertainty about food supply $(n=53)$

\begin{tabular}{|c|c|c|c|c|c|}
\hline & \multicolumn{5}{|c|}{ Frequency in the past 30 days } \\
\hline & Never & $\begin{array}{l}\text { Once or } \\
\text { twice }\end{array}$ & $\begin{array}{l}\text { Three to } 10 \\
\text { times }\end{array}$ & $\begin{array}{l}\text { More than } \\
10 \text { times }\end{array}$ & Total \\
\hline $\begin{array}{l}\text { Number who were anxious and } \\
\text { uncertain about food supply }\end{array}$ & 6 & 2 & 19 & 26 & 53 \\
\hline
\end{tabular}

Inefficient crop production methods may have resulted in poor yields, thus increasing the gardeners' anxiety and uncertainty about household food supply. Agricultural extension officers rarely visited community gardeners to give advice. Community gardens in the Maphephetheni uplands were mostly tended by women, who were already overburdened by household chores to the extent that they were unable to spend sufficient time gardening (Chingondole, 2006). This may have meant that crops were not watered regularly or sufficiently, and planting and harvesting were done late. The result was that production for 
the household was unpredictable, so that households had to rely on social grants, remittances and other off-farm activities to meet their food needs (NDA, 2002).

During periods of food scarcity, some household members accepted in-kind payments of food instead of cash for work rendered. Table 2 confirms that there was a significant and positive relationship between an increase in household anxiety and uncertainty about food supply and an increase in the total value of food from in-kind payments.

Table 2: Spearman's correlation coefficient between household characteristics and anxiety and uncertainty about food supply $(\mathbf{n}=53)$

\begin{tabular}{|c|c|}
\hline Household sources of food & Household anxiety and uncertainty \\
\hline Purchases & $\begin{array}{c}0.153 \\
(0.274)\end{array}$ \\
\hline Gifts & $\begin{array}{c}0.155 \\
(0.268)\end{array}$ \\
\hline In-kind payments & $\begin{array}{c}0.323^{*} \\
(0.018)\end{array}$ \\
\hline Community gardens & $\begin{array}{c}0.065 \\
(0.644)\end{array}$ \\
\hline Home gardens & $\begin{array}{c}0.065 \\
(0.644)\end{array}$ \\
\hline \multicolumn{2}{|l|}{ Household sources of income } \\
\hline Household per capita income & $\begin{array}{c}-0.128 * * \\
(0.359)\end{array}$ \\
\hline Wages & $\begin{array}{l}-0.128 \\
(0.359)\end{array}$ \\
\hline Social grants & $\begin{array}{c}-0.386^{* *} \\
(0.004)\end{array}$ \\
\hline Migrants & $\begin{array}{l}-0.254 \\
(0.067)\end{array}$ \\
\hline Household and community garden char & \\
\hline Number of people per household & $\begin{array}{c}0.009 \\
(0.001)\end{array}$ \\
\hline Number of people per community garden & $\begin{array}{c}0.639 * * \\
(0.001)\end{array}$ \\
\hline
\end{tabular}

$* *=$ Correlation is significant at the 0.01 level (2-tailed).

$*$ = Correlation is significant at the 0.05 level (2-tailed) of statistical significance.

Numbers in brackets refer to the $P$ values.

Accepting in-kind payments could make household members who are unable to render services in exchange for food (such as children, and sick, elderly and disabled people) more vulnerable to food insecurity. The recipients of in-kind payments were unable to negotiate the amount and type of food given, which led to further anxiety and uncertainty about the quantity and quality of food received. In addition, these payments were made only once a day - often the only meal consumed. In-kind payment systems, if adopted by all members of the household, could threaten already vulnerable household members and exacerbate household food insecurity by eroding collective responsibility for seeking longer-term coping strategies to ensure the household has enough to eat. Such hand-to-mouth existence threatens household 
and livelihood resources such as productive assets (tools, equipment, draught animals etc.), increasing long-term vulnerability to food insecurity.

Social grants were the main stable source of income for the surveyed community gardeners, contributing $48 \%$ of total income. As incomes (including those from social grants) increased, anxiety and uncertainty about household food supply decreased significantly.

Community gardens in the Maphephetheni uplands were each being used by an average of 17 households, which meant an average area of $224 \mathrm{~m}^{2}$ per household. The average household size was equivalent to four adults. As the number of households using a community garden increased, anxiety and uncertainty about household food supply increased (reflected as a statistically significant relationship). The households' demand for food is expected to increase as the population increases because of births and the return of migrant household members who retire or are retrenched from urban employment. This expectation of increased demand, against a background of low agricultural productivity and diminished alternative sources of household incomes exacerbates anxiety and uncertainty about food supply.

\section{Poor quality of food consumption}

The survey households produced a few staple foods: maize, amadumbe (taro) and some horticultural crops. However, they relied on purchases as the main source of food. Lack of crop diversity, coupled with low incomes, meant that these households ate few high quality foods. Household members purchased relatively cheap foods from local spaza shops, vendors or supermarkets in Durban and Hillcrest to cope with low incomes.

Of the 53 surveyed households, 50 reported that they were not able to eat the foods they preferred and that they ate only a small variety of foods. All households reported eating foods they did not like at least once a month (Table 3). According to Coates et al. (2006), the categories shown in Table 3 represent the least severe, intermediate and most severe negative coping strategies respectively. Thirty-one of the surveyed households had used these strategies for more than a third of the month prior to the survey.

Table 3: Households using coping strategies involving poor quality food consumption $(\mathbf{n}=53)$

\begin{tabular}{|lccccc|}
\hline & \multicolumn{5}{c}{ Frequency in the past 30 days } \\
\cline { 2 - 6 } Strategies & Never & Once or twice & $\begin{array}{c}\text { Three to } 10 \\
\text { times }\end{array}$ & $\begin{array}{c}\text { More than } 10 \\
\text { times }\end{array}$ & Total \\
\hline $\begin{array}{l}\text { Not able to eat } \\
\text { preferred foods }\end{array}$ & 3 & 6 & 12 & 32 & 53 \\
$\begin{array}{l}\text { Eating only a } \\
\text { limited variety } \\
\text { of food }\end{array}$ & 3 & & & & 53 \\
\\
$\begin{array}{l}\text { Having to eat } \\
\text { foods that are } \\
\text { not preferred }\end{array}$
\end{tabular}


Consumption of poor quality foods can have a long-term negative effect on household food security since it affects household members' health. Young children may suffer lower cognitive development and weak school performance. Such poor performers drop out of school and are unable to secure well-paying jobs, becoming a burden on households. Mature household members receiving inadequate supplies of quality food become vulnerable to vitamin and mineral deficiencies (FAO, 2005). Sick household members increase the burden on able-bodied members and put a strain on the household budget. Other household members are forced to spend time and resources taking care of the sick, further stretching household labour demand and increasing food insecurity. Pregnant mothers unable to access good quality foods may give birth to low weight children and poorly developed children with limited potential when mature, further increasing food insecurity (Quisumbing \& MeinzenDick, 2001). Household members requiring specialised diets, such as infants, the sick and the elderly, risk developing medical complications because of poor quality or unsuitable food.

Table 4 shows the relationship between poor consumption and the characteristics of the surveyed households. Low per capita income was statistically related to not being able to eat preferred foods, consumption of a limited variety of foods, and consumption of foods that were not preferred. Depending on social grants and being recipients of migrant remittances were also significantly related to the same negative consumption strategies. Households reported remittances as unreliable and low. This finding corroborates Bonti-Ankomah's observation (2001) that households in South Africa's rural areas have limited livelihood strategies and depend on limited incomes, rendering them vulnerable to food insecurity.

Table 4: Spearman's correlation coefficient between household characteristics and quality of food consumed $(\mathbf{n}=53)$

\begin{tabular}{|lccc|}
\hline & \multicolumn{2}{c|}{ Quality of food consumed by households } \\
\cline { 2 - 4 } Household sources of income & $\begin{array}{l}\text { Not able to eat } \\
\text { preferred kinds } \\
\text { of foods }\end{array}$ & $\begin{array}{c}\text { Eating a limited } \\
\text { variety of foods }\end{array}$ & $\begin{array}{l}\text { Eating foods } \\
\text { that are not } \\
\text { preferred }\end{array}$ \\
\hline Household per capita income & $-0.523 * *$ & $-0.538^{* *}$ & $-0.464 * *$ \\
Wages or salaries earned & $(0.001)$ & $(0.001)$ & $(0.001)$ \\
Social grants & 0.076 & 0.122 & 0.230 \\
Migrant remittances & $(0.589)$ & $(0.358)$ & $(0.098)$ \\
Household and community garden & $-0.452^{* *}$ & $-0.523 * *$ & $-0.540^{* *}$ \\
characteristics & $(0.001)$ & $(0.001)$ & $(0.001)$ \\
\hline Number of household members & $-0.459 * *$ & -0.268 & -0.355 \\
& $(0.001)$ & $(0.052)$ & $(0.009)$ \\
Size of community garden & & & -0.026 \\
Number of community garden members & $0.542 * *$ & 0.096 & $(0.855)$ \\
& $(0.002)$ & $(0.496)$ & $-0.674 * *$ \\
\hline
\end{tabular}

$* *=$ Correlation is significant at the 0.01 level (2-tailed).

$*$ = Correlation is significant at the 0.05 level (2-tailed) of statistical significance.

Numbers in brackets refer to the $P$ values. 
The community gardens and individual plots in our survey were small. Table 4 shows that the smaller a household's plot in a community garden, the more that household adopted erosive consumption strategies, compromising productivity and nutrition. Similarly, the more households there were sharing a community garden, the more frequently those households applied less desirable consumption strategies, with possible negative livelihood and health implications.

\section{Insufficient quantities of food consumed}

The 53 households in the survey responded to questions about what they did when they did not have enough food. These negative coping strategies are shown in order of increasing severity in Table 5. Most of the surveyed households reduced their portion sizes, ate fewer meals, or went completely without food because resources had been inadequate at some point in the month prior to the survey. The responses make it clear that they generally consumed insufficient quantities of food, and this, over short or longer periods, has negative consequences for productivity, livelihoods, health and food security.

Table 5: Coping strategies when food is inadequate $(n=53)$

\begin{tabular}{|c|c|c|c|c|c|}
\hline \multirow[b]{2}{*}{ Strategies } & \multicolumn{5}{|c|}{ Frequency in the last 30 days } \\
\hline & Never & $\begin{array}{c}\text { Once or } \\
\text { twice }\end{array}$ & $\begin{array}{c}\text { Three to } 10 \\
\text { times }\end{array}$ & $\begin{array}{c}\text { More than } \\
10 \text { times }\end{array}$ & Total \\
\hline \multirow{2}{*}{$\begin{array}{l}\text { Ate a smaller meal than } \\
\text { they needed }\end{array}$} & 9 & 3 & 17 & 24 & 53 \\
\hline & 5 & 5 & 18 & 25 & 53 \\
\hline \multicolumn{6}{|l|}{ Ate fewer meals in a day } \\
\hline & 13 & 15 & 21 & 4 & 53 \\
\hline \multicolumn{6}{|l|}{$\begin{array}{l}\text { Experienced total lack of } \\
\text { food due to lack of } \\
\text { resources }\end{array}$} \\
\hline & 31 & 11 & 9 & 2 & 53 \\
\hline & 37 & 2 & 10 & 4 & 53 \\
\hline $\begin{array}{l}\text { Went the whole day and } \\
\text { night without eating due } \\
\text { to lack of food }\end{array}$ & & & & & \\
\hline
\end{tabular}

Household members consuming inadequate quantities of food may become prone to diseases. Sick household members may require treatment and care, perpetuating the cycle of food insecurity. In extreme cases, household members may resort to unethical or demeaning methods of obtaining food such as begging, eating from dustbins, prostitution, theft or robbery. Analysis of the relationships between household sources of income, household and community garden characteristics and the frequency of resorting to strategies commonly associated with insufficient food consumption are shown in Table 6. 
Table 6: Spearman's correlation coefficient between household and community garden characteristics and household behaviour associated with insufficient food consumption $(n=53)$

\begin{tabular}{|c|c|c|c|c|c|}
\hline & & & Household be & iour & \\
\hline $\begin{array}{l}\text { Household } \\
\text { sources of } \\
\text { income }\end{array}$ & $\begin{array}{l}\text { Eating a } \\
\text { smaller meal }\end{array}$ & $\begin{array}{l}\text { Eating fewer } \\
\text { meals in a } \\
\text { day }\end{array}$ & $\begin{array}{l}\text { Experiencing } \\
\text { total lack of } \\
\text { food due to } \\
\text { lack of } \\
\text { resources }\end{array}$ & $\begin{array}{l}\text { Going to } \\
\text { sleep at night } \\
\text { hungry due } \\
\text { to lack of } \\
\text { food }\end{array}$ & $\begin{array}{l}\text { Going whole day } \\
\text { and night without } \\
\text { eating anything } \\
\text { due to lack of food }\end{array}$ \\
\hline Household per & $-0.258 * *$ & $-0.568 * *$ & -0.010 & -0.004 & -0.032 \\
\hline पर & $(0.062)$ & $(0.001)$ & $(0.943)$ & $(0.764)$ & $(0.818)$ \\
\hline Wage or salary & 0.233 & 0.111 & -0.005 & -0.049 & -0.059 \\
\hline & $(0.093)$ & $(0.430)$ & $(0.970)$ & $(0.725)$ & $(0.625)$ \\
\hline Social grant & -0.310 & $-0.400 *$ & -0.085 & -0.041 & -0.024 \\
\hline & $(0.024)$ & $(0.003)$ & $(0.543)$ & $(0.770)$ & $(0.863)$ \\
\hline Migrant & -0.224 & -0.151 & 0.088 & 0.106 & 0.265 \\
\hline & $(0.107)$ & $(0.279)$ & $(0.533)$ & $(0.449)$ & $(0.055)$ \\
\hline $\begin{array}{l}\text { Household and co } \\
\text { garden character }\end{array}$ & $\begin{array}{l}\text { amunity } \\
\text { tics }\end{array}$ & & & & \\
\hline Number of people & 0.210 & 0.126 & 0.112 & 0.193 & 0.135 \\
\hline & $(0.132)$ & $(0.368)$ & $(0.423)$ & $(0.166)$ & $(0.334)$ \\
\hline $\begin{array}{l}\text { Number of } \\
\text { community } \\
\text { garden members }\end{array}$ & $0.232 *$ & $0.368 * *$ & 0.266 & -0.049 & -0.121 \\
\hline & $(0.094)$ & $(0.007)$ & $(0.054)$ & $(0.725)$ & $(0.387)$ \\
\hline Area of & $-0.370 * *$ & $-0.443 * *$ & 0.060 & -0.009 & $-0.081 *$ \\
\hline $\begin{array}{l}\text { garden per } \\
\text { household }\left(\mathrm{m}^{2}\right)\end{array}$ & $(0.006)$ & $(0.001)$ & $(0.178)$ & $(0.949)$ & $(0.566)$ \\
\hline
\end{tabular}

Table 6 shows that the lower the household per capita income the higher the frequency of eating smaller meals and fewer meals per day; and the more members per garden and the smaller the plot sizes, the more households reported eating smaller meals and going to bed hungry.

\section{Household food insecurity access scale score (HFIAS score)}

The HFIAS score ranged from four to 27 ( $27=$ most severe food insecurity). The average HFIAS score was 16.2. The survey showed that 10 had an HFIAS score of 10 and below, and 14 had scores of 20 and above. Comparisons between the HFIAS score and household 
incomes showed that 34 of the surveyed households were in the lower household per capita quartile (< R176.25 per month or 55\% of the 2000 national poverty line). Only four households were in the upper per capita income quartile (> R528.76 per month). Generally, as household incomes increased, HFIAS scores decreased. Recipients of social grants were more food insecure on the HFIAS scale (Table 7).

Table 7: Pearson's correlation coefficients between HFIAS scores and household sources of income and food $(n=53)$

\begin{tabular}{|c|c|}
\hline Sources of household income & HFIAS score \\
\hline \multirow[t]{2}{*}{ Household per capita income } & $-0.604 * *$ \\
\hline & $(0.001)$ \\
\hline \multirow[t]{2}{*}{ Wage or salary earned } & 0.134 \\
\hline & $(0.339)$ \\
\hline \multirow[t]{2}{*}{ Social grant } & $-0.526 * *$ \\
\hline & $(0.001)$ \\
\hline \multirow[t]{2}{*}{ Migrant remittances } & -0.078 \\
\hline & $(0.578)$ \\
\hline \multicolumn{2}{|l|}{ Sources of food } \\
\hline \multirow[t]{2}{*}{ Purchases } & $0.348 *$ \\
\hline & $(0.011)$ \\
\hline \multirow[t]{2}{*}{ Gifts } & 0.265 \\
\hline & $(0.056)$ \\
\hline \multirow[t]{2}{*}{ In-kind payments } & 0.213 \\
\hline & $(0.126)$ \\
\hline \multirow[t]{2}{*}{ Community gardens } & -0.054 \\
\hline & $(0.703)$ \\
\hline \multirow[t]{2}{*}{ Home gardens } & 0.048 \\
\hline & $(0.733)$ \\
\hline \multicolumn{2}{|c|}{ Household and community garden characteristics } \\
\hline \multirow[t]{2}{*}{ Number of members in community garden } & $0.543 * *$ \\
\hline & $(0.001)$ \\
\hline \multirow[t]{2}{*}{ Size of community garden $\left(\mathrm{m}^{2}\right)$} & $-0.594 * *$ \\
\hline & $(0.001)$ \\
\hline \multirow[t]{2}{*}{ Number of people in household } & 0.142 \\
\hline & $(0.310)$ \\
\hline \multirow[t]{2}{*}{ Visit by agricultural extension officer } & $-0.329 *$ \\
\hline & $(0.016)$ \\
\hline
\end{tabular}

$*$ = Correlation is significant at the 0.05 level (2-tailed).

$* *=$ Correlation is significant at the 0.01 level (2-tailed).

Numbers in brackets refer to $P$ values. 
Where households reported purchasing food, there was a corresponding and statistically significant increase in the HFIAS score, showing that depending on garden produce alone increased food insecurity. An increase in the number of garden members per garden and smaller plot sizes was also significantly related to increased food insecurity through the HFIAS score. Visits by extension officers to community gardens decreased the HFIAS scores, showing that extension programmes a positive effect on garden productivity.

\section{Household food insecurity access prevalence}

The surveyed households were grouped into food security categories (Coates et al., 2006). Table 8 shows that 47 households were severely food insecure. None were food secure; rather, most of them were anxious and uncertain about food availability. They frequently used negative strategies that erode the possibility of improving their food security in the future.

Table 8: Proportion of households in each food security category $(n=53)$

\begin{tabular}{|lcccc|}
\hline & \multicolumn{3}{c|}{ Food security categories (Coates et al., 2006) } \\
\cline { 2 - 5 } & Food secure & $\begin{array}{c}\text { Mildly food } \\
\text { insecure }\end{array}$ & $\begin{array}{l}\text { Moderately food } \\
\text { insecure }\end{array}$ & $\begin{array}{l}\text { Severely food } \\
\text { insecure }\end{array}$ \\
$\begin{array}{l}\text { Number of } \\
\text { household in each } \\
\text { category }\end{array}$ & 0 & 1 & 4 & 48 \\
$\begin{array}{l}\text { Proportion of } \\
\text { households in } \\
\text { each category }\end{array}$ & $0 \%$ & $4 \%$ & $7 \%$ & $89 \%$ \\
\hline
\end{tabular}

As established above, the surveyed households had low incomes, which increased their food insecurity and anxiety about food supply and frequent use of negative and erosive strategies. As the number of members in a community garden increased and plot size decreased, households experienced greater food insecurity. Eleven households in the second quartile were classified as severely food insecure. Despite relatively high incomes, two of the upper quartile income households were classified as severely food insecure. This may indicate that an income of R528.76 per month was inadequate to meet household consumption needs.

\section{Conclusions and recommendations}

Community gardens were found not to contribute significantly to household food security for 53 households participating in community gardening in the Maphephetheni uplands. However, the contribution of the gardens to consumption cannot be entirely ignored particularly for households with low incomes and those depending on social grants. While participating in a community garden did not ensure food security, there is evidence that negative consumption patterns were avoided and access to food improved if plot sizes were adequate. However, improved productivity and greater access to land could improve household food security by increasing the amount of food available and generating income to supplement production. 
It is recommended that appropriate agricultural and nutritional advice, through an agricultural extension service, be given to participating members to improve the quality and quantity of production and encourage participation. Crop theft needs to be controlled by monitoring the gardens and punishing the thieves, and community gardens should be fenced to prevent animals destroying crops. The issue of land availability needs to be addressed through community and other redress systems to grant communities less marginal and more accessible, productive land close to water sources for irrigation. Where irrigation is not possible, drought tolerant varieties should be introduced in order to increase crop yields and extend seasonality. Programmes are needed to support community garden members engaged in economically viable non-farm projects to increase household incomes are needed, and could provide production incentives and a market for increased production.

\section{References}

ACFCGN (Australian City Farms and Community Gardens Network), 2002. Community gardening: The benefits. www.communitygarden.org.au/about/benefits.html Accessed 3 July 2006.

AFSIC (Alternative Farming Systems Information Centre), 2007. Community supported agriculture. www.nal.usda.gov/afsic/pubs/csa/csa.shtml Accessed 25 April 2007.

Armstrong, P, Lekezwa, B \& Siebrits, K, 2009. Poverty remains the priority for South Africa. Www.sangonet.org.za/article/poverty-remains-priority-sa Accessed 20 March 2011.

AU/NEPAD (African Union/ New Partnership for Africa's Development), 2009. Comprehensive African Agricultural Development Programme Framework for African Food Security. NEPAD, MidRand.

Berti, PR, Krasavec, J \& Fitzgerald, S, 2004. A review of the effectiveness of agricultural interventions in improving nutrition outcomes. Public Health Nutrition 7, 559-609.

Bonnard, P, 2001. Improving the nutrition impacts of agriculture interventions: Strategy and policy brief. Food and Nutrition Technical Assistance Project, Washington, DC. www.fantaproject.org/downloads/pdfs/NutAg_Mar01.pdf Accessed 13 May 2006.

Bonti-Ankomah, S, 2001. Addressing food insecurity in South Africa. www.sarpn.org.za/EventPapers/Land/20010605Bonti.pdf Accessed 24 April 2006.

Carletto, C, Masangano, C, Bergeron, G \& Morris, S, 2001. Using group ratings to assess household food security: Empirical evidence from southern Africa. Development Southern Africa 18(5), 541-52.

Chadha, ML \& Olouch, MO, 2003. Home-based vegetable gardens and other strategies to overcome micronutrient malnutrition in developing countries. FAO Food, Nutrition and Agriculture Report 32/2002. ftp://ftp.fao.org/docrep/fao/005/y8346m/y8346m02.pdf Accessed 20 March 2011.

Charlton, KE \& Rose, D, 2002. Quantitative indicators from a food expenditure survey can be used to target the food insecure in South Africa. Journal of Nutrition 132(11), 3235-42.

Chingondole, SM, 2006. Investigation of the socio-economic impact of morbidity and mortality on women's coping strategies among community garden clubs in Maphephetheni, KwaZulu-Natal. Unpublished PhD thesis, African Centre for Food Security, School of Agricultural Sciences and Agribusiness, University of KwaZuluNatal, Pietermaritzburg.

Coates, J, Swindale, A \& Bilinsky, P, 2006. Household Food Insecurity Access Scale (HFIAS) for measurement of food access: Indicator guide. 
www.fantaproject.org/downloads/pdfs/HFIAS\%20Guide.pdf Accessed 16 May 2006.

Faber, M, 2007. Achieving nutritional impact with vitamin A-rich vegetable gardens. Proceedings of the Orange-fleshed Sweet Potato Symposium, Pretoria, 3 October. www.mrc.ac.za/techncalpolcybriefs/sweet\%20potato\%200ctober\%202007opspsymp proceedings\%20Nutrition\%203.pdf Accessed 20 March 2011.

Faber, M, Schwabe, C \& Drimie, S, 2009. Dietary diversity in relation to other household food security indicators. International Journal of Food Safety, Nutrition and Public Health 2(1), 1-15.

FANTA (Food and Nutrition Technical Assistance), 2005. Measuring household food insecurity. Workshop II report. October 19, Washington DC. www.fantaproject.org/downloads/pdfs/MHFI_Workshop_Oct05.pdf Accessed 1 June 2006.

FANTA (Food and Nutrition Technical Assistance), 2007. Simple tools for measuring household access to food and dietary diversity. International Workshop, 21-23 March, Nairobi. Nutrition and Food Safety Division of FAO, Rome.

FAO (Food and Agriculture Organisation of the UN), 2005. High-level dialogue on financing for development: Meeting the Millennium Development Goals - financing for food security, agriculture and rural development. General Assembly - 59th session contribution by FAO, IFAD and WFP. New York, 27-28 June, 2005.

ftp://ftp.fao.org/docrep/fao/meeting/009/ae911e/ae911e00.pdf Accessed 26 April 2007.

FAO (Food and Agriculture Organisation of the UN), 2007. Organic Agriculture and Food Security. International Conference, 3-5 May, Rome. ftp://ftp.fao.org/paia/organicag/ofs/OFS-2007-2.pdf Accessed 20 March 2011.

FAO (Food and Agriculture Organisation of the UN), 2008. The state of food insecurity in the world 2008: High food prices and food insecurity - Threats and opportunities. ftp://ftp.fao.org/docrep/fao/011/i0291e/i0291e00.pdf Accessed 4 September 2009.

Glover, T, Parry, D \& Shinew, K, 2005. Building relationships, accessing resources: Mobilising social capital in community garden contexts. Journal of Leisure Research 37(4), 450-74.

Glover, T, Shinew, K \& Parry, D, 2005. Association, sociability and civic culture: The democratic effect of community gardening. Leisure Sciences 27, 75-92.

Green, JM, \& Erskine, SH, 1999. Solar (photovoltaic) systems, energy use and business activities in Maphephetheni, KwaZulu-Natal. Development Southern Africa 16(2), 221-37.

Green, JM, Wilson, M \& Cawood, W, 2001. Maphephetheni rural electrification (Photovoltaic) programme: The constraints on adoption of solar home systems. Development Southern Africa 18(1), 11-30.

Hazell, P \& Diao, X, 2005. The role of agriculture and small farms in economic development. www.ifpri.org/events/seminars/2005/smallfarms/sfproc/SO1_hazell.pdf Accessed 25 April 2007.

Hendriks, SL, 2003. The potential for nutritional benefits from increased agricultural production in rural KwaZulu-Natal. South African Journal of Agricultural Extension $32,28-44$.

Hendriks, SL, 2005. The challenges facing empirical estimation of food (in)security in South Africa. Development Southern Africa 22 (1), 103-23.

Hendriks, SL \& Msaki, MM, 2009. The impact of smallholder commercialisation of organic crops on food consumption patterns, dietary diversity and consumption elasticities. Agrekon 48(2), 184-99.

Hoddinott, J, 1999. Choosing outcome indicators of household food security. IFPRI (International Food Policy Research Institute), Washington, DC. 
HSRC (Human Sciences Research Council), 2004. Food security in South Africa: Key policy issues for the medium term. Integrated Rural Development: Position paper.

www.sarpn.org.za/documents/d0000685/Food_security_SA_January2004.pdf Accessed 26 May 2006.

IFPRI (International Food Policy Research Institute), 2005. Is agriculture still important for economic development and poverty reduction? Washington DC. IFPRI.

www.ifpri.org/PUBS/newsletters/IFPRIForum/200509/IF12comment.asp Accessed 25 April 2007.

IFPRI (International Food Policy Research Institute), 2007. The pilot food price subsidy scheme in the Philippines. Washington DC, IFPRI. www.ifpri.org/pubs/abstract/61/rr61ch09.pdf Accessed 22 April 2007.

IFPRI (International Food Policy Research Institute), 2008. Global food crises: Monitoring and assessing impact to inform policy responses. IFPRI Issues Brief Number 55, October. www.ifpri.org/sites/default/files/publications/ib55_0.pdf Accessed 5 September 2009.

Kirsten, J \& Moldenhauer, W, 2006. Measurement and analysis of rural household income in a dualistic economy: The case of South Africa. Agrekon 45(1), 60-77.

Kirsten J, May J, Hendriks S, Lyne M, Machete C \& Punt, C, 2007. The poverty alleviation and food security role of agriculture in South Africa. In Brescani, F \& Valdé, A (Eds), Beyond Food Production: The Role of Agriculture in Poverty Reduction. FAO, Rome, pp. 188-221.

Kirsten, J, Townsend, R \& Gibson, C, 1998. Determination of agricultural production to household nutritional status in KwaZulu-Natal, South Africa. Development Southern Africa 15(4), 573-87.

Labadarios, D, Steyn, N, Maunder, E, Macintyre, U, Swart, R, Gericke, G, Huskisson, J, Danhauser, A, Vorster, HH \& Nesamvuni, EA, 2000. The National Food Consumption Survey (NFCS): Children aged 1-9 years, South Africa, 1999. Department of Health: Directorate of Nutrition, Pretoria.

Machethe, C, 2004. Agriculture and poverty in South Africa: Can agriculture reduce poverty? www.sarpn.org.za/documents/d0001005/P1125-AgriculturePoverty_Machethe_2004.pdf Accessed 11 September 2006.

Malakoff, D, 1995. Community gardening: A key to food security. http://communitygarden.org/docs/learn/articles/cgakeytofoodsecurity.pdf

Accessed 5 November 2010.

Marsh, R, 1998. Building on traditional gardening to improve household food security. www.fao.org/docrep/x0051t/X0051t02.htm. Accessed 15 December 2010.

Mashinini, V, 2001. Managing communal vegetable production in Lesotho: The case of communal gardens. Africanus 31(2), 6-16.

Maunder, EMW \& Meaker, JL, 2007. The current and potential contribution of home grown vegetables to diets in South Africa. Water SA 33, 3.

Maxwell, D, Watkinson, B, Wheeler, R \& Collins, G, 2003. The Coping Strategy Index: A tool for rapidly measuring food security and the impact of food aid programmes in emergencies. Paper presented at FAO international workshop on food security in complex emergencies: Building policy frameworks to address longer term programming challenges, 23-25 September, Tivoli. FAO, Rome.

May, J, 1998. Poverty and inequality in South Africa. Report prepared for the Office of the Executive Deputy President and the Inter-Ministerial Committee for Poverty and Inequality. www.polity.org.za/html/govdocs/reports/poverty.html?rebookmark=1

Accessed 19 November 2006. 
Meth, C \& Dias, R, 2004. Increases in poverty in South Africa: 1999-2002. Development Southern Africa 21(1), 59-85.

Minde, IJ, Chilonda, P \& Hilmy, S, 2008. Rising global food prices: Policy challenges and options for southern Africa. Regional Strategic Analysis and Knowledge Support System for Southern Africa (ReSAKSS-SA) Issues Brief 006. Pretoria, ReSAKSSSA.

Mjonono, M, Ngidi, M \& Hendriks, SL, 2009. Food insecurity coping strategies at Embo. In Hendriks, SL \& Lyne, MC (Eds), Does Food Security Improve when Smallholders Access a Niche Market? Lessons from the Embo Community in South Africa. African Centre for Food Security, Pietermaritzburg, pp. 107-14.

Motloung, B \& Mears, R, 2002. Combating poverty in South Africa. Development Southern Africa 19(4), 531-43.

National Treasury, 2003. Intergovernmental Fiscal Review. National Treasury, Pretoria.

NDA (National Department of Agriculture ), 2002. The Integrated Food Security Strategy for South Africa. NDA, Pretoria.

Oxfam, 2007. Chronic food insecurity in southern Africa and Oxfam's response to the 2005-6 food crisis. www.oxfam.org.uk/what_we_do/emergencies/country/safrica05/update_july.htm. Accessed 22 April 2007.

Parliamentary Monitoring Group, 2008. Towards an Anti-Poverty Strategy for South Africa. Discussion Document. www.pmg.org.za/files/docs/081023anti-povertystrategy.pdf Accessed 15 December 2010.

Parry, D, Glover, T \& Shinew, K, 2005. Mary, Mary quite contrary, how does your garden grow? Examining gender roles and relations in community gardens. Leisure Studies 24(2), 177-92.

Philip, D \& Rayham, I, 2004. Vulnerability and poverty: What are the causes and how are they related? Term paper for Interdisciplinary Course, International Doctoral Studies Programme at ZEF (Zentrum für Entwicklungsforschung), Bonn.

Quisumbing, AR \& Meinzen-Dick, RS, 2001. Empowering women to achieve food security. www.ifpri.org/2020/focus/focus06/focus06.pdf. Accessed 29 April 2007.

Quisumbing, A, Meinzen-Dick, R, Bassett, L, Usnick, M, Pandofelli, L \& Morden, C, 2008. Helping women respond to the global food price crisis. IFPRI (International Food Policy Research Institute) Policy Brief 7. IFPRI, Washington, DC.

RAPS (Rural Areas Power Solutions) Consulting (Pty) Ltd, 2004. Maphephetheni Development Programme, KwaZulu-Natal, South Africa. www.hedon.info/goto.php/MaphephetheniDevelopmentProgrammeSouthAfrica Accessed 12 August 2006.

Riely, F, Mock, N, Cogill, B, Bailey, L \& Kenefick, E, 1999. Food security indicators and framework for use in the monitoring and evaluation of food aid programmes. FANTA, Washington, DC.

Swindale, A \& Ohri-Vichaspati, P, 2005. Measuring household food consumption: A technical guide. www.fantaproject.org/downloads/pdfs/foodcons.pdf Accessed 28 August 2006.

UN (United Nations), 2006. Reducing vulnerability of the girl child in poor rural areas. http://www.un.org/womenwatch/daw/egm/elim-disc-violgirlchild/ObserverPapers/IFAD\%20-\%20Hartl.pdf Accessed 29 April 2007.

UNDP (United Nations Development Programme), 2003. The challenge to sustainable development in South Africa: Unlocking people's creativity. South African Human Development Report. Oxford University Press, Oxford. 
UNDP (United Nations Development Programme), 2010. List of Countries by Human Development Index.

http://en.wikipedia.org/wiki/List_of_countries_by_Human_Development_Index\#Afri ca Accessed 15 March 2011.

VIC (Vitamin Information Centre), 2001. National Food Consumption Survey in Children Aged 1-9 Years: South Africa 1999. Medical Update Number 37, VIC, Isando.

Webb, NL, 2000. Food gardens and nutrition: Three South African case studies. Tydskrif vir Gesinsekologie en Verbruikerswetenskappe 28, 62-7.

Wolfe, WS \& Frongillo, EA, 2001. Building household food security measurement tools from the ground up. Food and Nutrition Bulletin 22(1), 5-12.

Woolard, I, 2002. An overview of poverty and inequality in South Africa. http://datafirst.cssr.uct.ac.za/resource/papers/woolard_2002.pdf Accessed 22 April 2007. 